\section{Mivacurium-induced neuromuscular blockade during sevoflurane and halothane anaesthesia in children}

Richard F. Kaplan MD, Michael Garcia MD, Raafat S. Hannallah MD FRCPC
The neuromuscular blocking effects of mivacurium during sevoflurane or halothane anaesthesia was studied in 38 paediatric patients aged 1-12 yr. All received premedication with midazolam, $0.5 \mathrm{mg} \cdot \mathrm{kg}^{-1}$ po and an inhalational induction with up to $3 \mathrm{MAC}$ of either agent in $70 \% \mathrm{~N}_{2} \mathrm{O}$ and $\mathrm{O}_{2}$. The ulnar nerve was stimulated at the wrist by a train-of-four stimulus every ten seconds and the force of adduction of the thumb recorded with a Myotrace force transducer. Anaesthesia was maintained with a one MAC end-tidal equivalent of either volatile agent for five minutes before patients received mivacurium $\left(0.2 \mathrm{mg} \cdot \mathrm{kg}^{-1}\right)$ iv. The onset of maximal blockade occurred in $2.4 \pm 1.26$ (mean $\pm S D$ ) $\min$ with halothane and $1.8 \pm$ 0.54 min with sevoflurane (NS). Four patients failed to achieve $100 \%$ block (3 halothane, 1 sevoflurane). The times from injection to 5,75 , and $95 \%$ recovery during sevoflurane $(9.8 \pm$ $2.6,19.5 \pm 4.4$, and $24.2 \pm 4.8 \mathrm{~min}$ ) were greater than during halothane anaesthesia $7.2 \pm 2.2,15.0 \pm 4.0,19.2 \pm 4.9 \mathrm{~min}$, respectively $(P<0.005)$. All patients demonstrated complete spontaneous recovery of neuromuscular function $\left(T_{1}>95 \%\right.$, $T_{4} / T_{I}>75 \%$ ) during the surgery which lasted 24-63 min. All

Key words

ANAESTHESIA: paediatric;

ANAESTHETICS, VOLATILE: halothane, sevoflurane; NEUROMUSCULAR RELAXANTS: mivacurium.

From the Departments of Anesthesiology and Pediatrics, Children's National Medical Center and George Washington University, Washington, DC.

Address correspondence to: Dr. R. Kaplan, Department of Anesthesiology, Children's National Medical Center, 111

Michigan Avenue, N.W., Washington, DC 20010.

Supported in part by a grant from Abbott Laboratories, Chicago, Illinois.

Presented in part at the Annual Meeting of the International Anesthesia Research Society, Orandao, Florida, March 1994. Accepted for publication 21st August, 1994. patients showed clinical signs of full recovery of neuromuscular blockade (i.e., headlift, gag, or cough). Pharmacological reversal was not required. It is concluded that following a single intubating dose of mivacurium, the time to maximum relaxation was not different during halothane and sevoflurane anaesthesia; recovery times to 5, 75 and $95 \%$ twitch height were longer during sevoflurane anaesthesia and neuromuscular reversal was not necessary.

L'activité neurobloquante du mivacurium pendant l'anesthésie au sévoflurane ou à l'halothane fait l'objet de cette étude réalisée chez 38 enfants de 1 à 12 ans. Tous ont été prémédiqués au midazolam $0,5 \mathrm{mg} \cdot \mathrm{kg}^{-1}$ et l'anesthésie est induite avec un agent volatil jusqu’à $M A C 3$ de l'un des agents dans du $\mathrm{N}_{2} \mathrm{O}$ à 70\%. Le nerf cubital était stimulé au poignet au train de quatre aux dix seconds et la force de l'adduction du pouce mesurée avec un transducteur de force Myotrace. L'anesthésie était entretenue avec l'équivalent MAC 1 d'un des deux agents volatils pendant cing minutes avant l'administration de mivacurium $\left(0,2 \mathrm{mg} \cdot \mathrm{kg}^{-l}\right)$. Le début du bloc maximum est survenu dans $2,4 \pm 1,26$ (moyenne $\pm S D$ ) min avec lhalothane et 1,8 $\pm 0,54 \mathrm{~min}$ avec le sévoflurane (NS). Quatre patients n'ont pas été bloqués à 100\% (trois avec l'halothane, un avec le sévoflurane). Lintervalle séparant linjection à $5 ; 75$, et $95 \%$ de la récupération pendant l'anesthésie au sévoflurane $(9,8 \pm$ 2,6, 19,5 $\pm 4,4$ et $24,2 \pm 4,8$ min) a été plus long que pendant l'anesthésie à l'halothane $(7,2 \pm 2,2,15,0 \pm 4,0,19,2 \pm 4,9$ min, respectivement $(P<0,005)$. An moniteur, chez tous les patients, la fonction neuromusculaire a récupéré spontanément $\left(T_{1}>95 \%, T_{4} / T_{1}>75 \%\right)$ au cours de la chirurgie qui a duré de 24-63 min. Tous les patients montraient aussi les signes cliniques d'une récupération complète (par ex., levée de la tête, réflexe pharyngé ou toux). Aucun antagoniste pharmacologique n'a été requis. Il est conclu que le délai jusqu'à la relaxation maximum après une seule dose d'intubation de mivacurium ne differe pas entre l'anesthésie à lhalothane et l'anesthésie au sévoflurane; les délais de retour à 5, 75 et $95 \%$ de la hauteur du twitch sont plus longs pendant l'anesthésie au sévoflurane 

et il n'est pas nécessaire d'antagoniser le bloc neuromuscu-
laire.

Mivacurium is a bis, benzylisoquinolone neuromuscular blocking agent which has a short duration of action due to spontaneous hydrolysis by plasma cholinesterase. ${ }^{1}$ Sevoflurane is a new potent inhalational agent with a blood gas partition coefficient of 0.6 . In children, sevoflurane has been demonstrated to have rapid induction and emergence characteristics. ${ }^{2}$ The combination of mivacurium and sevoflurane may have advantages in children undergoing short surgical procedures. A previous study has demonstrated potentiation of the neuromuscular effects of mivacurium by halothane compared with nitrous oxide/narcotic anaesthesia in children. ${ }^{3}$ This study investigated the interaction of mivacurium with sevoflurane versus halothane in paediatric patients.

\section{Methods}

After institutional approval and parental informed consent were obtained, 38 ASA Physical Status I or II patients aged 1 to $12 \mathrm{yr}$ scheduled for short surgical procedures requiring tracheal intubation were randomized to receive either sevoflurane or halothane anaesthesia. Approximately $30 \mathrm{~min}$ before induction, the children received premedication with midazolam, $0.5 \mathrm{mg} \cdot \mathrm{kg}^{-1}$ po. An inhalational induction was performed using up to three MAC of the respective inhalational agents in a 70\% nitrous oxide/oxygen mixture. After the eyelash reflex was abolished, an intravenous catheter was placed and $1 \mu \mathrm{g} \cdot \mathrm{kg}^{-1}$ fentanyl was administered. The ulnar nerve was stimulated via surface electrodes at the wrist by a supramaximal train-of-four stimulus generated every ten seconds by a Digistim II generator. The tension generated by the contraction of the adductor pollicis was monitored using a Myotrace monitor and recorded on an Omega paper chart recorder. The volatile agent was adjusted to a level equivalent to one MAC $(2.5 \%$ end-tidal sevoflurane or $0.8 \%$ halothane end-tidal - adjusted for age) for five minutes. End-tidal $\mathrm{CO}_{2}$ was maintained at 35 to 45 $\mathrm{mmHg}$ and the axillary temperature $>35.5^{\circ} \mathrm{C}$. End-tidal concentrations were measured via a catheter at the lips using a Datex Capnomac Ultima sidestream analyzer. After stabilization, mivacurium $0.2 \mathrm{mg} \cdot \mathrm{kg}^{-1} i v$ was injected as a rapid bolus.

The time to and magnitude of maximal blockade were measured. The trachea was intubated during maximal blockade. Intubation conditions were scored on a threepoint scale: excellent, if no vocal cord or other patient movement occurred during intubation; satisfactory, if some movement of the vocal cords or other patient movement occurred; and poor, if the vocal cords were adducted
TABLE I Demographic variables (mean 土 SD)

\begin{tabular}{llll}
\hline & Halothane & Sevofurane & $P$ \\
\hline Age (mo) & $47.7 \pm 23.3$ & $57.4 \pm 32.1$ & 0.30 \\
Weight (kg) & $17.5 \pm 5.5$ & $20.7 \pm 10.6$ & 0.27 \\
Surgical time (min) & $40.2 \pm 10.8$ & $41.5 \pm 11.8$ & 0.72 \\
\hline
\end{tabular}

or coughing occurred. No other muscle relaxants were given during the procedure. Anaesthesia was maintained with $1 \mathrm{MAC}$ of inhalation agent plus $70 \% \mathrm{~N}_{2} \mathrm{O} / \mathrm{O}_{2}$ mixture throughout the study (measured near the proximal end of the endotracheal tube). Twitch height was continuously monitored until the time of full spontaneous, stable recovery of twitch height. The times to $5,25,75$, and $95 \%$ twitch height recovery of the first twitch of the train-of-four were measured in all children. In all cases the trachea was extubated when the twitch height had fully recovered and the patient demonstrated clinical evidence of complete neuromuscular recovery (cough, gag reflex, sustained leg or head lift). No neuromuscular reversal agents were used. In the Post Anaesthesia Care Unit (PACU), oxygen saturation was continuously monitored using pulse oximetry until fully awake. All patients received supplemental oxygen until fully awake. A Steward recovery score ${ }^{4}$ was used to assess motor activity, respiration, consciousness, and colour. Any clinical evidence of muscle weakness (i.e., impaired response to stimulation, positioning, suctioning, etc.) and/or of airway complications (obstruction or $\mathrm{SpO}_{2}<90 \%$ ) were noted. All results are expressed in mean and standard deviation and were compared using Student's two sample $\mathrm{t}$ test. Results were considered statistically significant when $P \leq 0.05$.

\section{Results}

Patients in the halothane and sevoflurane groups were comparable with respect to age, weight and duration of anaesthesia and surgery (Table I).

\section{Onset}

Maximal block occurred in $2.40 \pm 1.26 \mathrm{~min}$ (mean \pm SD) with halothane and $1.8 \pm 0.54 \mathrm{~min}$ with sevoflurane $(P-N S)$ (Table II). All patients who achieved $100 \%$ block had excellent intubating conditions. Four patients failed to achieve $100 \%$ block: three in the halothane and one in the sevoflurane group (Table III). The intubating conditions at the time of maximum block in these children were rated as excellent in two, and satisfactory in the remaining two patients.

\section{Duration}

Times from injection to $5,25,75$, and $95 \%$ recovery of 
TABLE II Response to mivacurium $\left(0.2 \mathrm{mg} \cdot \mathrm{kg}^{-1}\right)$ (mean $\pm \mathrm{SD}$ )

\begin{tabular}{lrrl}
\hline Time (min) to: & Halothane & Sevoflurane & $P$ \\
\hline $\begin{array}{l}\text { Maximum block } \\
\text { (range) }\end{array}$ & $\begin{array}{r}2.4 \pm 1.26 \\
(1.04-3.48)\end{array}$ & $\begin{array}{c}1.8 \pm 0.54 \\
(1.44-6.2)\end{array}$ & 0.06 \\
Recovery & & & \\
$5 \%$ & $7.2 \pm 2.2$ & $9.8 \pm 2.6$ & 0.005 \\
$25 \%$ & $9.8 \pm 2.6$ & $12.8 \pm 3.6$ & 0.09 \\
$75 \%$ & $15.0 \pm 4.0$ & $19.5 \pm 4.4$ & 0.002 \\
$95 \%$ & $19.2 \pm 4.9$ & $24.2 \pm 4.8$ & 0.003 \\
$25-75 \%$ & $5.5 \pm 2.1$ & $6.6 \pm 2.8$ & 0.2 \\
\hline
\end{tabular}

TABLE III Patients with submaximal blockade

\begin{tabular}{llll}
\hline Patient & Agent & $\begin{array}{l}\text { Maximum } \\
\text { block }\end{array}$ & $\begin{array}{l}\text { Injection to } \\
\text { max block (min) }\end{array}$ \\
\hline 1 & HALO & $67 \%$ & 4.52 \\
2 & HALO & $62 \%$ & 6.20 \\
3 & SEVO & $82 \%$ & 3.48 \\
4 & HALO & $88 \%$ & 2.88 \\
\hline
\end{tabular}

twitch height are shown in Table II. Times from injection to 5,75 and $95 \%$ were each longer with sevoflurane $(9.8$ $\pm 2.6,19.5 \pm 4.4$, and $24.2 \pm 4.8 \mathrm{~min}$ ) than with halothane $(7.2 \pm 2.2,15.0 \pm 4.0$, and $19.2 \pm 4.9$ minutes, respectively, $P<0.005$ ).

One patient in the sevoflurane group had a more prolonged period of relaxation than all others. The times to $5,25,75$, and $95 \%$ recovery in this patient were 17.2 , $20.4,30.2$, and 36.9 min respectively. Because of this patient's prolonged response, plasma cholinesterase and dibucaine numbers were tested. The plasma cholinesterase level was 2.4 units $\cdot \mathrm{ml}^{-1}$ (normal: $2.1-4.7$ units $\cdot \mathrm{ml}^{-1}$ ). The dibucaine number was $77 \%$ (normal 70-85\%).

At the completion of surgery, all of the patients had spontaneous return of $>95 \% \mathrm{~T}_{1}$ twitch height and a $\mathrm{T}_{1}$ / $\mathrm{T}_{4}$ ratio $>75 \%$. No patient received anticholinesterase drugs for neuromuscular reversal. In addition, all patients demonstrated clinical evidence of adequate neuromuscular transmission before extubation was attempted. Extubation was uncomplicated in all patients. No clinical evidence of residual neuromuscular blockade was noted in the PACU.

\section{Complications}

One patient had an episode of laryngospasm during transport to the PACU. One patient developed a rash following the administration of mivacurium. The erythema was confined to one arm and no wheals occurred. No clinically apparent change in the vital signs was noted and the rash resolved spontaneously. No other complications attributable to mivacurium occurred.

\section{Discussion}

Onset

The dose of $0.2 \mathrm{mg} \cdot \mathrm{kg}^{-1}$ of mivacurium was used in this study because this dose is used clinically to facilitate tracheal intubation in children and has been previously studied in conjunction with other anaesthetics. This dose has been shown to be $2 \times \mathrm{ED}_{95}$ dose in children aged 2-12 yr in the presence of $1 \%$ inspired halothane. ${ }^{1}$ Our study shows that the time to maximum paralysis following mivacurium $0.2 \mathrm{mg} \cdot \mathrm{kg}^{-1} \dot{v}$ was not different in children anaesthetized with sevoflurane or halothane (1.8 and 2.4 min, respectively). The times of maximum onset in both the halothane and sevoflurane groups were comparable to previously reported times of $1.9 \mathrm{~min}$ with halothane and 1.6 min with $\mathrm{N}_{2} \mathrm{O}$ /opioid reported by Goudsouzian using the same dose of mivacurium. ${ }^{\prime}$ The average time of exposure to halothane in Goudsouzian's paper was similar to the five minutes exposure in our study (personal communication, N. Goudsouzian). Mangat reported maximum paralysis following mivacurium $0.2 \mathrm{mg} \cdot \mathrm{kg}^{-1}$ in $2.4 \mathrm{~min}$ following thiopentone, halothane, $\mathrm{N}_{2} \mathrm{O} / \mathrm{O}_{2}$ anaesthesia. ${ }^{5}$ Sarner reported that a dose of 0.25 $\mathrm{mg} \cdot \mathrm{kg}^{-1}$ maximum blockade occurred at $1.1 \mathrm{~min}$ with halothane. $^{3}$ Therefore, the times of onset with mivacurium reported in the present study using halothane or sevoflurane are consistent with previous studies using various anaesthetics.

The similar effect of sevoflurane and halothane on onset time of mivacurium may seem to conflict with their dissimilar effect on duration of action. Sevoflurane prolongs the duration of action compared with halothane. The postulated mechanisms by which inhaled anaesthetics augment neuromuscular blocking agent effects are: (1) increased delivery of relaxant to the neuromuscular junction by increasing muscle blood flow, (2) prejunctional effects, (3) decreased post-junctional sensitivity to depolarization, and (4) direct distal effects on the muscle. ${ }^{6}$ Studies comparing the effects of volatile anaesthetics on neuromuscular blockade usually allow $30^{7}$ to $45^{8} \mathrm{~min}$ for the anaesthetic to have its effect on the neuromuscular junction before the muscle relaxant is given. Studies have shown that the effect of halothane is not time-dependent ${ }^{9}$ while the effect of enflurane is. ${ }^{10}$ The effect of duration of sevoflurane exposure on neuromuscular blocking drug effect has not been examined. In our study and others ${ }^{1}$ only five minutes elapsed from constant end-tidal concentration of inhalational agent to injection of mivacurium. This timing is more consistent with the clinical paediatric induction sequence of inhalation induction quickly followed by injection of muscle relaxant. It is possible that the similar onset times with halothane and sevoflurane in our study are because the inhalation agent did 
not have time to effect the above mechanisms. By contrast, the prolonged duration of blockade of sevoflurane vs halothane may be due to these mechanisms since more time elapsed for their full effect to take place.

Four patients (three halothane, one sevoflurane) failed to develop complete blockade despite receiving 0.2 $\mathrm{mg} \cdot \mathrm{kg}^{-1}$ of mivacurium. A careful evaluation of the possible causes of this result was undertaken. All medications were injected into a free-flowing intravenous line. The blood pressure cuffs were not on the extremity where the iv cannula was located. This makes it unlikely that an incomplete dose of mivacurium was absorbed. Mivacurium does not require refrigeration. It is recommended that the drug be stored at $15-25^{\circ} \mathrm{C}$ and that freezing and exposure to ultraviolet light be avoided. These recommendations were followed in our study. The force transducer monitor was carefully placed to isolate the adduction of the thumb and the stimulus was set at $10 \%$ greater than supramaximal stimulus. These two processes nearly eliminate direct muscle stimulation as a cause of a false twitch height signal. " Further, two of the four patients who were not $100 \%$ paralyzed showed clinical evidence of incomplete relaxation during intubation.

A possible cause of this resistance to mivacurium is hypermetabolism of the drug. A variant of pseudocholinesterase enzyme produces hypermetabolism of succinylcholine ${ }^{12}$ and possibly mivacurium. It is theoretically possible that these four patients had this anomalous enzyme resulting in the degradation of mivacurium before its neuromuscular effects became apparent. The prevalence of this enzyme is estimated to be 1 in 770 to 1 in 2600.12 Although these four patients' plasma cholinesterase activities were not measured, the probability of four patients with a hypermetabolic enzyme occurring in a cohort of 38 patients is unlikely. Technical and enzymerelated problems are therefore unlikely to be the cause of failure to achieve complete neuromuscular blockade in this group.

Our results are different from those of Goudsouzian et al. who reported complete neuromuscular blockade in all children receiving mivacurium $0.2 \mathrm{mg} \cdot \mathrm{kg}^{-1}$ during halothane or $\mathrm{N}_{2} \mathrm{O}$ /opioid anaesthesia. ' Mangat, however, noted that 6 of 33 children aged 2-12 yr failed to achieved 95-100\% neuromuscular blockade despite mivacurium $0.2 \mathrm{mg} \cdot \mathrm{kg}^{-1}$ in the presence of halothane. ${ }^{5}$ The four patients in the present study may thus represent an inability of $0.2 \mathrm{mg} \cdot \mathrm{kg}^{-1}$ to produce complete neuromuscular blockade in all normal children.

\section{Duration}

The time to $5 \%$ recovery of the group which had received halothane was $7.2 \pm 2.2 \mathrm{~min}$. This is similar to previously reported recovery times of $8.6 \mathrm{~min}$ by Goudsouzian. ${ }^{1}$ The recovery times to 5,75 , and $95 \%$ block for the sevoflurane group were longer than those in the halothane group. The cause of the lack of a difference in the recovery at $25 \%$ is not obvious but the result might have been different if more patients had been studied.

The prolongation of recovery may be explained by greater potentiation of neuromuscular blockade by sevoflurane than halothane. Sarner et al. previously reported a decrease in the $\mathrm{ED}_{50}$ and $\mathrm{ED}_{95}$ of mivacurium in the presence of halothane compared to $\mathrm{N}_{2} \mathrm{O}$ /opioid, and a prolongation in the time to recovery, without an increase in the recovery index $\left(\mathrm{T}_{25-75}\right) .{ }^{3}$ In a study of the effect of sevoflurane on vecuronium and pancuronium, sevoflurane produced potentiation of the neuromuscular block. ${ }^{13}$ Potentiation of vecuronium-induced blockade has been demonstrated during sevoflurane and enflurane anaesthesia compared with neuroleptanaesthesia and halothane anaesthesia. ${ }^{14}$ The duration of blockade by vecuronium is prolonged by 2.2 MAC enfluranenitrous oxide, but not by isoflurane. ${ }^{7}$ Thus, potent volatile agents variably potentiate nondepolarizing neuromuscular blocking drugs. Although no direct comparison of the potentiation of various halogenated agents with mivacurium has been previously conducted, our study demonstrates that sevoflurane has a potentiating effect at one MAC end-tidal concentrations in children. Even so, complete spontaneous recovery following a single intubating dose of mivacurium was found in all patients during these procedures which lasted $24-63 \mathrm{~min}$.

One of the patients in the sevoflurane group had a prolonged block compared with the others. The possibility of low plasma cholinesterase activity or a genetic variant of plasma cholinesterase was considered. Low concentrations of cholinesterase activity may cause prolongation of mivacurium-induced blockade, but levels must be markedly low to cause a severe prolongation. ${ }^{15}$ Patients homozygous for atypical plasma cholinesterase enzyme reportedly have a four- to five-hour duration of neuromuscular blockade from mivacurium. ${ }^{16-18}$ The normal dibucaine number and cholinesterase activity in our patient exclude both homozygous and heterozygous atypical cholinesterase variants as well as homozygous silent, fluoride resistant, and $J,{ }^{19,20} \mathrm{~K}$, and $\mathrm{H}$ variants. ${ }^{19,20}$ Other rare heterozygous states such as normal-fluoride as well as normal-silent cannot be excluded in our patient. Thus, this patient's prolonged blockade may represent either one of the above rare heterozygous genetic variants or the longer range of normal in the paediatric population.

\section{Reversal}

No patient in this study required pharmacological reversal of neuromuscular blockade and no complications of neu- 
romuscular blockade were noted in the PACU. The degree of neuromuscular blockade was closely monitored and recorded, and all children had returned to greater than $95 \%$ twitch height by the end of surgery.

Avoidance of reversal agents may result in less nausea and vomiting in the recovery room, ${ }^{21}$ reduces the possibility of medication error, and may decrease the cost of the anaesthetic. A single intubating dose of mivacurium, when carefully monitored as in this study, safely offers the option of not using reversal agents in most paediatric patients even in short surgical cases. It must be stressed that adequacy of reversal by neuromuscular monitoring as well as clinical signs of full recovery (inspiratory pressure, vital capacity, head lift, etc.) should be obtained before the decision to avoid reversal agents is made.

\section{Conclusion}

Mivacurium, $0.2 \mathrm{mg} \cdot \mathrm{kg}^{-1}$, provides adequate, relatively rapid onset neuromuscular blockade for tracheal intubation in children. The 10\% incidence of incomplete blockade mitigates against the use of mivacurium at this dose in situations where absolutely no coughing or vocal cord response may be safely tolerated. The rapid offset characteristics of mivacurium are prolonged by the use of sevoflurane relative to halothane. Still, reversal of a single intubating dose of mivacurium is not required in all patients if neuromuscular monitoring of the ratio of the train-of-four response, response to tetanic stimulus, and clinical criteria reveal adequate neuromuscular function.

\section{References}

1 Goudsouzian NG, Alifimoff JK, Eberly C, et al. Neuromuscular and cardiovascular effects of mivacurium in children. Anesthesiology 1989; 70: 237-42.

2 Naito Y, Tamai S, Shingu K, Fujimori $R$, Mori $K$. Comparison between sevoflurane and halothane for paediatric ambulatory anaesthesia. $\mathrm{Br} \mathrm{J}$ Anaesth 1991; 67 : $387-9$.

3 Sarner JB, Brandom BW, Woelfel SK, et al. Clinical pharmacology of mivacurium chloride (BW B1090U) in children during nitrous oxide-halothane and nitrous oxidenarcotic anesthesia. Anesth Analg 1989; 68: 116-21.

4 Steward DJ. A simplified scoring system for the postoperative recovery room. Can Anaesth Soc J 1975; 22: 111-3.

5 Mangat PS, Evans DEN, Harmer M, Lunn JN. A comparison between mivacurium and suxamethonium in children. Anaesthesia 1993; 48: 866-9.

6 Miller RD, Savarese JJ. Pharmacology of muscle relaxants and their antagonists. In: Miller RD (Ed.). Anesthesia, 3rd ed. New York: Churchill Livingstone, 1990; $399-400$.
7 Rupp SM, Miller RD, Gencarelli PJ. Vecuronium-induced neuromuscular blockade during enflurane, isoflurane, and halothane anesthesia in humans. Anesthesiology 1984; 60: 102-5.

8 Miller RD, Way WL, Dolan WM, Stevens WC, Eger EI II. Comparative ncuromuscular effects of pancuronium, gallamine, and succinylcholine during forane and halothane anesthesia in man. Anesthesiology 1971; 35: 509-14.

9 Miller RD, Crique M, Eger EI II. Duration of halothane anesthesia and neuromuscular blockade with $\mathrm{d}$ tubocurarine. Anesthesiology 1976; 44: 206-10.

10 Stanski DR, Ham J, Miller RD, Sheiner LB. Timedependent increase in sensitivity to dTC during enflurane anesthesia. Anesthesiology 1979; 51: S269.

11 Viby-Mogensen J. Neuromuscular monitoring. In: RD Miller (Ed.). Anesthesia, 3rd ed. New York: Churchill Livingstone 1990; 1217.

12 Foldes $F F(E d$.). Enzymes in Anesthesiology. New York, Heidelberg, Berlin: Springer Verlag, 1978.

13 Itagaki T, Tai K, Katsumata N, Suzuki $H$. A clinical and experimental study on potentiation with sevoflurane of neuromuscular blocking effects of vecuronium and pancuronium. Masui 1988 37: 943-54.

14 Saitoh Y, Toyooka H, Amaha K. Recoveries of posttetanic twitch and train-of-four responses after administration of vecuronium with different inhalation anaesthetics and neuroleptanaesthesia. Br J Anaesth 1993; 70: 402-4.

15 Qstergaard D, Jensen FS, Jensen E, Skovgaard LT, VibyMogensen $J$. Influence of plasma cholinesterase activity on recovery from mivacurium-induced neuromuscular blockade in phenotypically normal patients. Acta Anaesthesiol Scand 1992; 36: 702-6.

16 Bevan DR. Prolonged mivacurium-induced neuromuscular block. Anesth Analg 1993; 77: 4-6.

17 Goudsouzian NG, d'Hollander AA, Viby-Mogensen J. Prolonged neuromuscular block from mivacurium in two patients with cholinesterase deficiency. Anesth Analg 1993; 77: 183-5.

18 Maddineni VR, Mirakhur RK. Prolonged neuromuscular block following mivacurium. Anesthesiology 1993; 78: 1181-4.

19 Lehmann H, Liddell J. Human cholinesterase (psuedocholinesterase): genetic variants and their recognition. $\mathrm{Br} \mathrm{J}$ Anaesth 1969; 41: 235-44.

20 Pantuck EJ. Plasma cholinesterase: gene and variations. Anesth Analg 1993; 77: 380-6.

21 Kao YJ, Mian T, McDaniel KE, Kleinman S, Arthur J, McCabe HJ. Neuromuscular blockade reversal agents induce postoperative nausea and vomiting. Anesthesiology 1992; 77: Al120. 